УДК 330.15:504.06

(C) 2014

Самойлік М. С., кандидат економічних наук

Полтавський національний технічний університет ім. Юрія Кондратюка

\title{
ЕКОНОМІЧНА МОДЕЛЬ РОЗВИТКУ СФЕРИ ПОВОДЖЕННЯ 3 ТВЕРДИМИ ВІДХОДАМИ РЕГІОНУ 3 УРАХУВАННЯМ ЕКОЛОГІЧНИХ ФАКТОРІВ
}

\section{Рецензент - доктор економічних наук, професор В. В. Писаренко}

Розроблено й науково обтрунтовано методику інтегральної моделі розвитку сфери поводження $з$ твердими відходами, щзо дає можливість приймати оптимальні рішення з екологічної та економічної точок зору у даній сфері. Розраховані системні витрати різних варіантів ефективності інвестування $i$ функціонування регіональної системи управління відходами. Розрахунки показали, щу економічна ефективність переробки відходів у порівнянні з полігонним захороненням значно вища, шчо пов'язано з величиною екологічних ризиків. Інтегральний економічний ефект - за розрахунковий десятирічний термін експлуатації установки з переробки 156 тис. тонн відходів у рік-становить 9,88 млн. гривень.

Ключові слова: тверді відходи, сфера поводження з твердими відходами, регіон, оцінка ризику здоров'ю населення, економіко-екологічна модель, оптимізація.

Постановка проблеми. Проблема взаємодії біосфери і людства в епоху, коли енергетичні можливості останнього стали порівняними 3 енергією процесів природного походження, вимагає не просто вивчення різних аспектів впливу людини на навколишнє середовище - вона вимагає створення системи, яка б давала змогу врахувати складне переплетення взаємновпливаючих чинників, що й визначає складність виниклих завдань. Складні самі по собі економічні, соціальні, політичні й інші проблеми виявилися пов'язаними в єдине ціле 3 проблемою стабільності біоти, зміною клімату, забрудненням середовища, вивченням нової сировинної бази тощо. Вирішення даної проблеми, як зазначив у своїх дослідженнях В. І. Вернадський, вимагає створення нового світового порядку, спрямованого на забезпечення скоординованих дій усієї світової спільноти по відвертанню екологічної катастрофи, тобто переходу до ноосферного розвитку, як розумно керованого співрозвитку людини, суспільства i природи, при якому задоволення життєвих потреб населення здійснюється без збитку для природи і майбутніх поколінь [1].

Нині в Україні ще не здоланий розрив у розумінні взаємозв'язку і взаємозалежності економі- чних і екологічних факторів розвитку. Економіка виступає як відособлена від природи сфера суспільно-виробничих відносин, а екологія - як навколишнє середовище, яке існує для вилучення природних ресурсів і асиміляції відходів. До того ж зростання відходів виробництва i споживання - одна із найактуальніших екологічних, економічних і соціальних проблем сучасного світу.

Суть цієї проблеми полягає в тому, що ефективне управління відходами $\epsilon$ одним із визначальних чинників якості довкілля, що відноситься до громадських благ. Будучи, 3 одного боку, джерелом забруднення довкілля, тверді відходи (TB) також виступають як джерело ресурсозабезпечення регіону за рахунок використання вторинних ресурсів.

Вирішення даного протиріччя пов'язано 3 максимально можливим залученням відходів у господарський обіг i ïx матеріально-енергетичною утилізацією, як техногенної сировини, на основі використання екологічно безпечних методів переробки відходів із найменшими економічними витратами.

Водночас однією з проблем - у процесі залучення інвестиційних коштів у сферу поводження 3 ТВ - $\epsilon$ проблема управління економікоекологічними ризиками, а саме формування механізмів їх зниження.

Існуючі на даний час підходи до удосконалення сфери поводження 3 ТВ в основному базуються на виборі технологій переробки і знешкодження, оцінки впливу на довкілля і здоров'я людини, які під час зводяться до порівняння 3 межами допустимих викидів і скидів, лімітів на розміщення відходів, що встановлюються для кожного конкретного суб'єкта, але передусім грунтуються на міркуваннях економічної доцільності та досягнення техніко-економічного ефекту; при цьому можливість зниження екологічних ризиків практично не розглядається.

$\mathrm{У}$ той же час зниження екологічних ризиків $\epsilon$ основним завданням у вирішенні проблем поводження з відходами. 


\section{EKOHOMIKA}

\begin{abstract}
Аналіз основних досліджень і публікацій,
\end{abstract} у яких започатковано розв'язання проблеми. Пошукам шляхів забезпечення ефективного функціонування сфери поводження 3 ТВ надається чимало уваги у роботах вітчизняних і зарубіжних учених - О. І. Бондаря [8], В. О. Онищенка, Ю. С. Голіка [5], О. В. Мороза, А. О. Свентуха [4], В. С. Міщенка, Г. П. Виговської [3] Т. П. Галушкіної, В. В. Чанга [9] та ін.

Зауважимо, що питання удосконалення системи регіонального управління сферою поводження 3 твердими відходами в рамках соціальноекономічної політики за допомогою формування ринкового механізму та його інститутів вивчені недостатньо. У той же час потрібно враховувати, що обгрунтування інвестиційних вкладень у сферу поводження 3 ТВ повинно спиратися на економіко-екологічну оцінку різних технологічних рішень у даній сфері з урахуванням соціальних аспектів. Особливої уваги потребує оптимізація економічних та екологічних критеріїв розвитку даної сфери. Тобто, виникає потреба у розробці економіко-екологічної моделі управління сферою поводження 3 твердими відходами для формування оптимальних сценаріїв екологічно безпечного, економічно мотивованого поводження $з$ відходами.

Мета дослідження: розробити і науково обгрунтувати методику оптимізації економікоекологічних рішень у сфері поводження з ТВ на основі інтегральної моделі розвитку даної системи, що враховує ринкові умови функціонування підприємств і вплив екологічних чинників; визначити альтернативні системи поводження з відходами для регіону з урахуванням соціо-екологоекономічних параметрів розвитку даної сфери.

Результати досліджень. Проблема вибору найбільш ефективної системи поводження 3 ТВ на сучасному етапі надзвичайно актуальна. Це обумовлено цілою низкою умов, які викликані переходом до ринкової економіки регіонів країни, вимогами міжнародних стандартів, документів і необхідністю отримання максимальної економічної ефективності. Порівняння різних інвестиційних проектів (або варіантів проекту) і вибір кращого з них, на основі міжнародної практики, рекомендується проводити з використанням різних показників, до яких відносять: чистий дисконтний дохід (ЧДД) або інтегральний ефект; індекс дохідності (ІД); внутрішню норму дохідності (ВНД); термін окупності (Р). Недолік вказаних критеріїв полягає в тому, що вони враховують окремі аспекти економічної ефективності й можуть протирічити один одному. Так, термін окупності не пов'язаний із терміном економічно- го життєвого циклу й не може бути реальним критерієм прибутковості, крім того даний показник внутрішньо передбачає однаковий рівень щорічних грошових надходжень від поточної господарської діяльності.

Показник ЧДД, незважаючи на всі переваги оцінки інвестицій, не дає відповіді на питання, пов'язані $з$ економічною ефективністю капіталовкладень. Так, наприклад, не можна оцінити розмір «резерву» (перевищення), розрахованого за даним нормативом рентабельності в разі порівняння різних варіантів проектів, особливо якщо сума інвестицій істотно відрізняється. Внутрішня норма доходності є більш точним показником у порівнянні з попередніми, але й цей критерій має свої недоліки. Один із них, зокрема, полягає у можливості того, що складний проект зі змінними величинами вхідних і вихідних грошових потоків протягом його життєвого циклу буде характеризуватися декількома різними значеннями ВНД через відмінності у структурі й хронології грошових потоків і відрахувань грошових коштів.

Для вибору найбільш раціонального варіанту бажано мати системний критерій, який враховує фактори й аспекти економічної ефективності. Враховуючи можливості розвитку об'єктів, які діють самостійно (акціонерна форма власності) 3 отриманням прибутку від утилізації ТВ, і беручи до уваги умову співставлення варіантів для різних варіантів інвестування, запишемо цільову функцію, яка характеризуватиме системний критерій, у вигляді [6]:

$$
\Pi=\Pi^{*}-\mathrm{E}_{\text {ИН }} \mathrm{K} \rightarrow \max ,
$$

де: $\Pi^{*}$ - прибуток, який зостається у розпорядженні об'єкта (підприємства), що працює у сфері поводження з ТВ, грн.; К - величина капі-

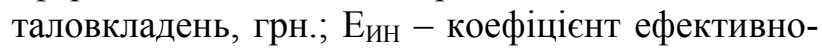
сті капітальних вкладень у варіанті, що розглядається.

Вираз (1) перепишемо стосовно специфіки підприємства, що функціонує у сфері поводження 3 ТВ. У даних умовах реалізація продукції виражається у вигляді плати за відходи, що збираються у їх власників $(\theta)$. У загальному випадку може здійснюватися складування і видалення на полігонах ТВ або сортування й глибока переробка $з$ отриманням та реалізацією напівфабрикатів і продуктів на суму (U). Названі варіанти суттєво різняться за величиною споживання земельних ресурсів $\left(\mathrm{H}_{3}\right)$ і значенням екологічних ризиків $\left(\mathrm{E}_{\mathrm{R}}\right) .3$ урахуванням вказаного, цільову функцію можна записати: 
ЕКОНОМIKA

$$
\Pi=\left(\theta+U-3_{s}\right)\left(1-\gamma_{H}\right)\left(1-\delta_{y u}\right)-3_{M}-H_{3}-H_{z}-E_{R}-E_{u i t} K \rightarrow \max ,
$$

де: $\boldsymbol{Z}$ - прибуток, який зостається у розпорядженні об'єкту, що працює у сфері поводження 3 ТВ, грн; $\theta_{t}$ - плата за приймання відходів, грн; $3_{s}-$ щорічні витрати виробництва, які віднесені до собівартості, грн; $\gamma_{н}$ - функція, що враховує систему державних, регіональних і місцевих податків; $\delta_{y s}-$ функція, що враховує умови участі засновників і інвесторів у розподілі прибутку; $3_{\mathrm{m}}$ - матеріальні й інші витрати, що не включаються в собівартість, грн; $\mathrm{H}_{3}$ - вартість земель, що виводяться з сільськогосподарського обігу, грн; $\mathrm{H}_{\varepsilon}-$ сумарні додаткові платежі, що включають плату за кредит, плату за понадлімітне забруднення довкілля тощо, грн; $\mathrm{E}_{R}-$ екологічний ризик, виражений у грошовій формі, грн; Е варіанті, що розглядається.

При наявній різниці варіантів, що порівнюються за надійністю функціонування, екологічною безпекою, виведенням земельних ділянок із господарського обігу тощо, у цільову функцію вводяться витрати на відповідні системи, які забезпечують співставлення варіантів, що порівнюються $\left(\Delta 3_{\text {пр }}\right)$. Розглядаючи величину цільової функції за період функціонування об'єкту (T), з урахуванням дисконтування, отримаємо формулу (4) на рисунку.

На основі приведених вище даних побудована інтегральна модель розвитку сфери поводження з відходами на основі оптимізації екологічних та економічних критеріїв (див. рис.). Запропонована економіко-екологічна модель розвитку сфери поводження з ТВ, яка враховує вплив екологічного фактора, особливості процесу поводження 3 $\mathrm{TB}$, а також ринкові умови функціонування підприємств, дасть можливість вибрати оптимальний варіант поводження 3 відходами у системі управління даною сферою.

У зв'язку з вищенаведеним, у сфері поводження $з$ ТВ необхідно виявити проекти, які будуть менш витратними і самоокупними. Розглянемо використання наведеної моделі у разі обгрунтування систем поводження з відходами для конкретних умов (зокрема м. Полтава), де щорічно утворюється близько 500 тис. м $^{3} /$ рік побутових відходів, при цьому на душу населення припадає $1,6 \mathrm{~m}^{3} /$ рік. Усього у місті накопичено 7,2 млн м відходів.

Поводження із зібраними ТВ у м. Полтава на даний час включає єдиний метод - ліквідаційний (вивезення на міське звалище побутових відходів). Потенційний економічний збиток за забруднення атмосферного повітря та водного середовища міським звалищем ТВ становить 2,331 млн грн, а також 0,590 млн грн - за забруднення грунтів [6]. Більшість із ресурсоцінних матеріалів, що входять до складу ТВ, вивозяться на міське звалище й лише частково відсортовуються на окремі $з$ них; до всього обсяги вивезення ре- сурсоцінних компонентів ТВ недостатньо контролюються.

Нині у м. Полтава фінансове забезпечення заходів щодо поводження з ТВ базується на зборах коштів від населення та організацій у вигляді тарифів і бюджетному фінансуванню [5]. У зв'язку з нестачею бюджетних коштів фінансування об'єктів здійснюється не в повному обсязі для ефективного розвитку систем утилізації відходів. Водночас спеціальні підприємства 3 переробки відходів здатні виділяти значну кількість компонентів із ТВ, які підлягають вторинній переробці (рециклінгу), а також виробляти компост. Проведемо порівняння підприємства 3 переробки відходів, яке можливо впровадити у дію у м. Полтава, та існуючої системи - експлуатація полігону ТВ.

Потрібно зауважити, що системи поводження 3 ТВ, засновані на вирішенні часткових проблем відходоутворюючих підприємств і окремих населених міст, не дивлячись на їх високу затратність, зазвичай, малоефективні. Спорудження локальних об'єктів утилізації ТВ у кожному місті, селищі чи на кожному підприємстві призводить до розпорошення коштів, необгрунтованого зростання витрат на захоронення відходів, не даючи змоги ефективно вирішувати проблему поводження з відходами у масштабах регіону. Виходом із ситуації, що склалася, $є$ розробка й реалізація регіональних комплексних систем поводження $з$ відходами, які базуються на створенні сучасних схем санітарної очистки населених міст, організації сітки внутрішньорегіональних, регіональних і міжрегіональних об'єктів утилізації відходів, ефективних систем збору і транспортування відходів із вилученням і утилізацією вторинної сировини та фракцій відходів, які мають ресурсний потенціал. Тому оцінку сценаріїв розвитку сфери поводження 3 ТВ у м. Полтава доцільно здійснювати, виходячи 3 наявної інфраструктури та системи управління у регіоні. 


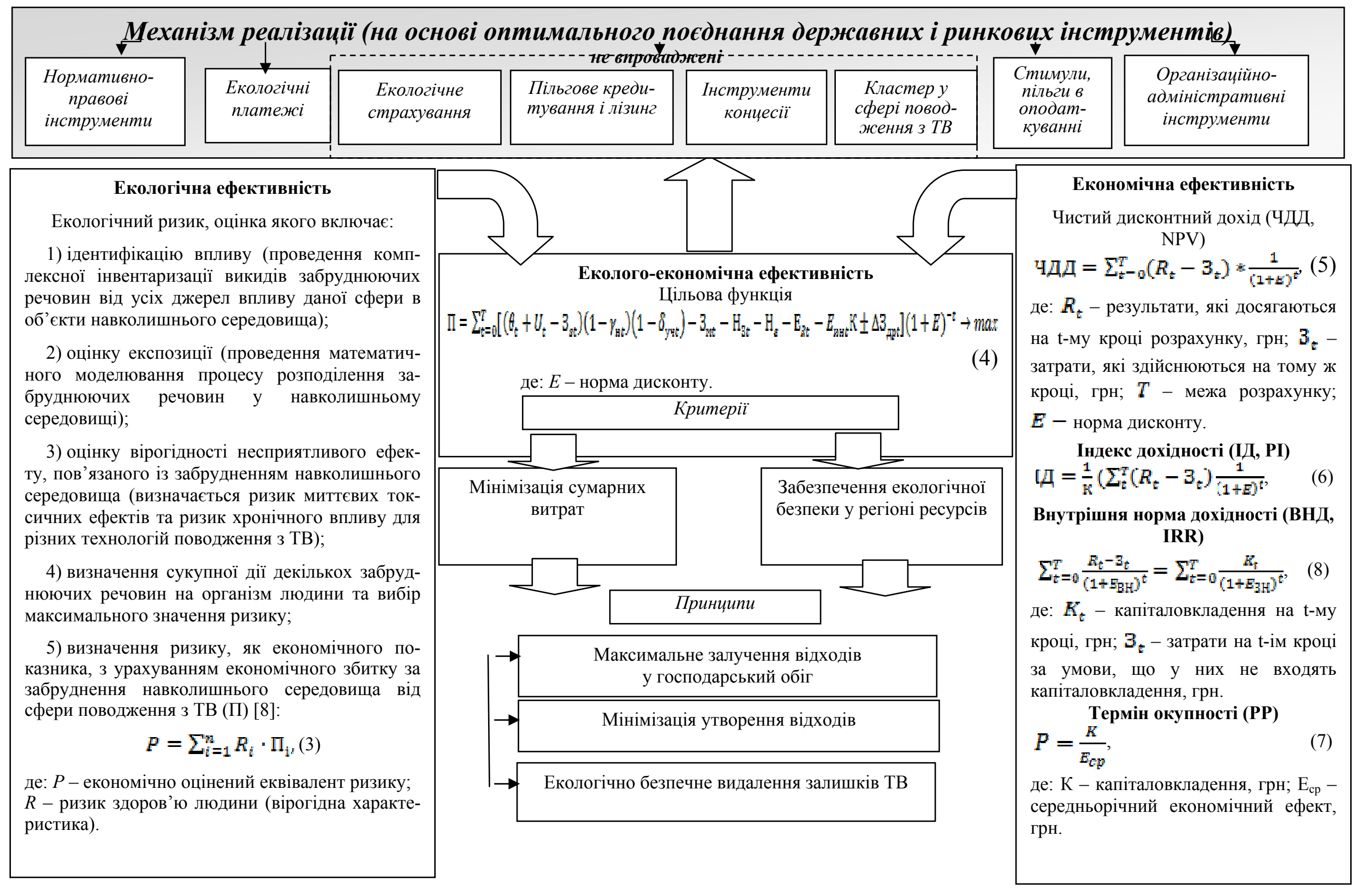




\section{Показники ефективності інвестицій у різні варіанти схем поводження з відходами *}

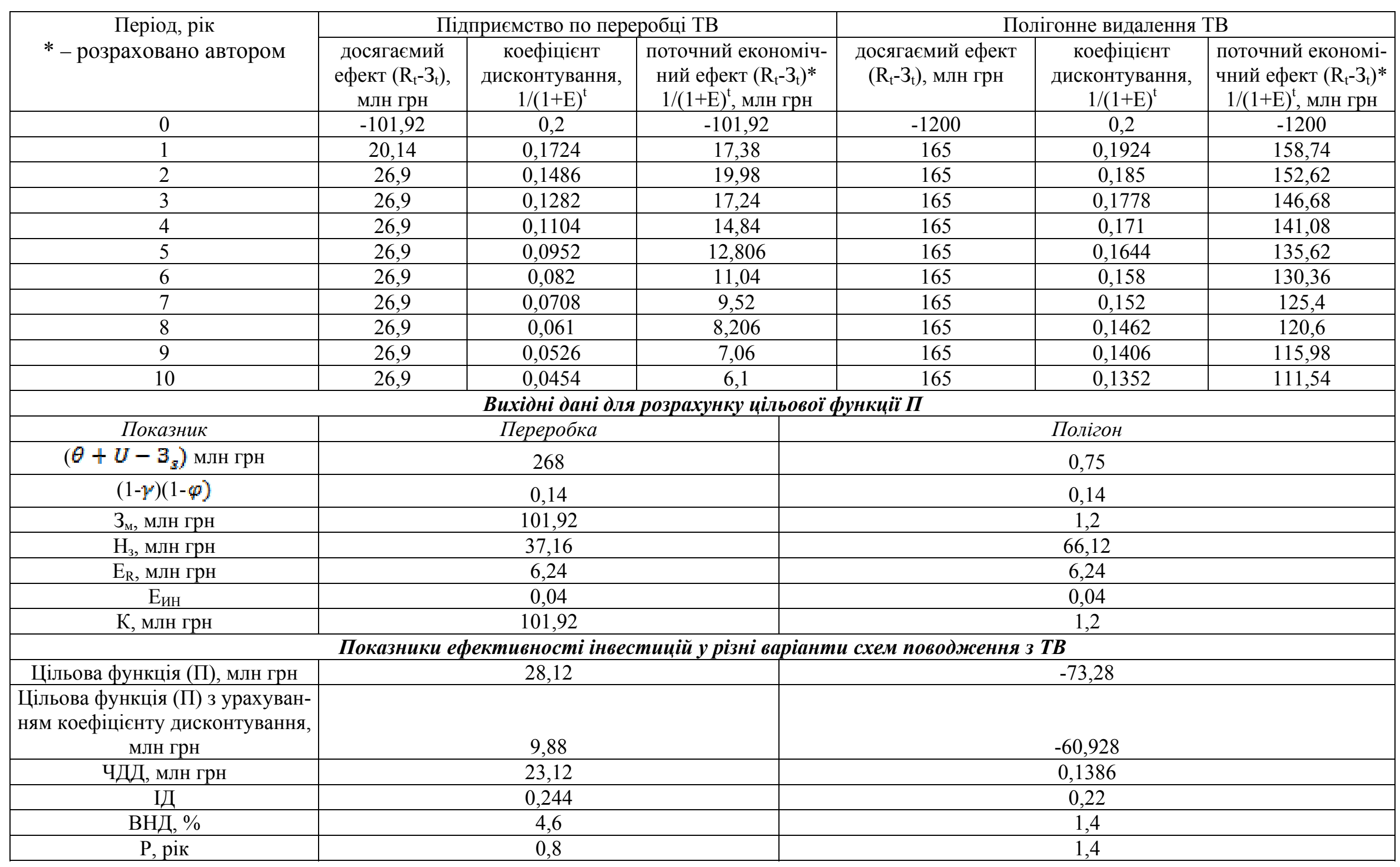




\section{EKOHOMIKA}

Будівництво переробного підприємства здійснюється протягом 18 місяців. Із початку функціонування підприємство 3 переробки ТВ планує отримання прибутку, починаючи з другого року й далі. Дохід підприємства вкладає надходження від реалізації продуктів переробки (U) - 31,82 млн грн і плати за приймання відходів (9,32 млн грн). Кількість відходів, які приймаються на підприємство, 156 тис. т/рік. Окупність підприємства становить 4 роки (див. табл.).

Для порівняння наведемо відповідні розрахунки для полігону ТВ. Вартість проектування і будівництва полігону потужністю 500 т за добу становить 3 млн грн, вартість обладнання для полігону 2 млн грн [2]. 3 урахуванням транспортних витрат, пов'язаних із доставкою відходів на полігон і витрат на обслуговуючий персонал, який працює у даній сфері, грошові кошти, які надходять на експлуатацію полігону, становлять 0,5 млн гривень. Окупність полігону -7 років (див. табл.).

У якості розрахункового терміну 3 визначення економічної ефективності взято 10 років. Вартість земель, що виводяться із сільськогосподарського обігу, розраховано за [6] і становлять 66,1 млн гривень. Екологічний ризик з урахуванням десяти років становить 6,24 млн гривень. Як видно із таблиці 1, для полігону значення цільової функції (П) є від'ємною складовою й становить 60,928 млн грн, що пояснюється вартістю земель, які вилучаються iз господарського обігу, і величиною екологічного ризику. Значення цільової функції для підприємства $з$ переробки ТВ - величина позитивна й стано-

\section{БІБЛІОГРАФІЯ}

1. Вернадський В.И. Биосфера и ноосфера / И. В. Вернадський. - М. : Айрис-пресс, 2004. - 576 с.

2. Інформація сайту Міністерства регіонального розвитку, будівництва та житлово-комунального господарства. [Электронный ресурс]. - Режим доступу: http://minregion.gov.ua/index.php?option=com_k2\&vie $\mathrm{w}=$ itemlist\&task $=$ category\&id $=378 \% 3$ Apobutov $\% \mathrm{D} 1 \%$ 96v\%D1\%96dxodi\&Itemid=170\&lang=uk

3. Міщенко B. C. Організаційно-економічний механізм поводження з відходами в Україні та шляхи його вдосконалення / В. С. Міщенко, Г. П. Виговська. - К. : Наукова думка, 2009. - 294 с.

4. Мороз O. В. Економічні аспекти вирішення екологічних проблем утилізації твердих побутових відходів / О.В.Мороз, А. О. Свентух, О. Т. Свентух. - Вінниця: УНІВЕРСУМ - Вінниця, 2003. - $110 \mathrm{c}$.

5. Онищенко В. О. Регіональна програма охорони довкілля, раціонального використання природних ресурсів та забезпечення екологічної безпеки з урахуванням регіональних пріоритетів вить 9,88 млн гривень. Таким чином, значення цільової функції показує ефективність переробки ТВ iз точки зору екологічної безпеки в рамках регіональної системи управління сферою поводження 3 відходами. За іншими критеріями (ЧДД, ІД, ВНД, Р) підприємство 3 переробки відходів також є ефективнішим порівняно 3 полігонним видаленням. Це пояснюється більш глибоким врахуванням економічної значимості раціонального використання природних i матеріальних ресурсів у системах управління утилізацією відходів.

Висновок. Таким чином, автором запропоновано й науково обгрунтовано методику інтегральної моделі розвитку сфери поводження 3 TВ, що дає змогу приймати оптимальні рішення 3 екологічної та економічної точок зору у сфері поводження 3 ТВ. Особливістю даної моделі є те, що вона сповна враховує вплив екологічних ризиків на економічні показники. На підставі запропонованого критерію розраховані системні витрати різних варіантів ефективності інвестування та функціонування регіональної системи управління поводженням iз ТВ. Розрахунки показали, що економічна ефективність переробки ТВ порівняно $з$ полігонним захороненням значно вища. Це передусім пов'язано 3 величиною екологічних ризиків, які значно вищі у разі полігонного видалення ТВ. Інтегральний економічний ефект за розрахунковий десятирічний термін експлуатації з урахуванням дисконтування становить, стосовно установки 3 переробки 156 тис. тонн ТВ у рік, понад 9,88 млн гривень.

Полтавської області [В. О. Онищенко, Ю. С. Голік, О. Е. Ілляш [та ін.]. - Полтава : Полтавський літератор, 2012. - 164 с.

6. Онищенко С. В. Еколого-економічна оцінка забруднення навколишнього середовища в системі екологічно безпечного розвитку регіонів України. Монографія. [С. В. Онищенко, М. С. Самойлік]. Полтава : ПолтНТУ, 2012. - 269 с.

7. Самойлік M. С. Оцінка ризику здоров’ю населення у сфері поводження 3 твердими відходами на регіональному рівні // Еколого-правові та економічні аспекти екологічної безпеки регіонів: 3б. VIII Міжнародної. наук.-практ. конф. - 2013. - С. 166-171.

8. Управління відходами: вітчизняний та зарубіжний досвід: посібник / [О. І. Бондар, В. С. Барановська, М. О. Баринов [та ін.]; за ред. О. І. Бондаря. К. : Айва Плюс Лтд, 2008. - 196 с.

9. Chang $W$. Integrated analysis of recycling and incineration programmes by goal programming techniques / W. Chang // Waste Management and Research. - 2009. - №5. - PP. 121-136. 